\title{
Invigorasi Mutu Fisiologis Benih Terung Ungu (Solanum melongena L.) Kadaluarsa dengan Beberapa Teknik Osmoconditioning
}

\author{
Physiological Quality Invigoration of Expired Eggplant Seed (Solanum melongena L.) by Some \\ Osmoconditioning Techniques \\ Pitri Ratna Asih \\ Program Studi Teknologi Benih, Politeknik Pembangunan Pertanian Yogyakarta. Magelang \\ e-mail: pitriratna@gmail.com
}

\begin{abstract}
ABSTRAK
Invigorasi merupakan salah satu metode yang digunakan untuk mengatasi benih yang telah mengalami deteriorasi. Osmoconditioning adalah teknik invigorasi dengan perlakuan hidrasi benih terkontrol dengan tujuan mempercepat proses imbibisi dan aktivasi enzim sehingga perkecambahan terjadi lebih cepat dan serempak. Penelitian ini bertujuan untuk mengetahui teknik osmoconditioning yang mampu meningkatkan mutu fisiologis benih terung yang telah lewat masa edar/kadaluarsa. Penelitian ini dilaksanakan secara acak lengkap faktor tunggal yaitu perlakuan osmoconditioning yang terdiri dari 9 (sembilan) perlakuan yaitu kontrol, air hangat, ekstrak bawang merah, Poli Etilen Glikol (PEG) $1 \%$, PEG 3\%, PEG 5\%, $\mathrm{KNO}_{3} 2 \mathrm{gr} / \mathrm{L}, \mathrm{KNO}_{3} 4 \mathrm{gr} / \mathrm{L}$, dan $\mathrm{KNO}_{3} 6 \mathrm{gr} / \mathrm{L}$. Masing-masing perlakuan terdiri dari 25 butir benih dan diulang 3 kali. Benih terung kadaluarsa 2 tahun 10 bulan telah mengalami deteriorasi dengan viabilitas $<80 \%$. Perlakuan osmoconditioning menggunakan $\mathrm{KNO}_{3}$ mampu meningkatkan viabilitas maupun vigor benih terung kadaluarsa nyata lebih baik dibandingkan kontrol dari pengamatan daya berkecambah, indeks vigor, bobot kering kecambah normal, serta tinggi kecambah. Perlakuan osmoconditioning dengan PEG menghasilkan panjang akar paling besar sebagai respon benih terhadap lambatnya imbibisi yang cenderung mengarah ke kondisi kekeringan.
\end{abstract}

Kata kunci: PEG, $\mathrm{KNO}_{3}$, Priming, Viabilitas Potensial, Vigor, Deteriorasi

\section{ABSTRACT}

Invigoration is one method used to resolve deteriorated seed. Osmoconditioning is an invigoration technique with controlled seed hydration treatment which aims to accelerate the process of imbibition and enzyme activation so that germination occurs more quickly and simultaneously. This study aims to determine the osmoconditioning technique which can improve the physiological quality of expired eggplant seeds. This research was arranged in a randomized complete design with single factor namely osmoconditioning treatment consisting of 9 (nine) treatments i.e. control, warm water, onion extract, Poly Ethylene Glycol (PEG) 1\%, PEG 3\%, PEG 5\%, $\mathrm{KNO}_{3} 2 \mathrm{gr} / \mathrm{L}, \mathrm{KNO}_{3} 4 \mathrm{gr} / \mathrm{L}$, dan $\mathrm{KNO}_{3} 6 \mathrm{gr} / \mathrm{L}$. Each treatment consisted of 25 seeds and was repeated 3 times. Expired eggplant seeds (2 years 10 months) have deteriorated with viability $<80 \%$. Osmoconditioning using $\mathrm{KNO}_{3}$ was able to increase the viability and vigor of expired eggplant seeds significantly better than control from the observation of germination, vigor index, dry weight of normal sprouts, and height of sprouts. Osmoconditioning treatment with PEG produced the longest root length in response to the slow rate of imbibition which tended to lead to drought conditions.

Keywords: $\mathrm{PEG}, \mathrm{KNO}_{3}$, Priming, Potential Viability, Vigor, Deterioration 


\section{PENDAHULUAN}

Terung (Solanum melongena L.) merupakan salah satu komoditas penyumbang keanekaragaman bahan sayuran bergizi bagi penduduk yaitu sebagai sumber vitamin, garam mineral terutama kandungan Vitamin A dan Fosfor (Muldiana dan Rosdiana, 2017). Terung memiliki potensi yang besar untuk dikembangkan karena kebutuhan pasar yang tinggi. Konsumsi terung per kapita dari tahun 2014 sebesar $2.434 \mathrm{~kg} / \mathrm{kapita} /$ tahun menjadi $2.668 \mathrm{~kg} / \mathrm{kapita} /$ tahun pada tahun 2018 (Pusdatin, 2018). Produksi dalam kurun 10 tahun terakhir (2009 - 2018) mengalami peningkatan dari 451.564 ton pada tahun 2009 menjadi 551.562 ton pada tahun 2018. Hasil mengalami peningkatan dari 12.19 ton/ha pada tahun 2017 menjadi 12.38 ton/ha pada tahun 2018. Badan Pusat Statistik mencatat bahwa pada tahun 2018, terung juga masuk dalam 17 (tujuh belas) jenis sayuran semusim yang diekspor oleh Indonesia dengan nilai 301.375 ton. Total nilai ekspor sayuran semusim tahun 2018 mencapai 11.82 juta US \$. (BPS, 2019).

Benih merupakan input utama untuk memproduksi buah terung dengan kebutuhan $150-300 \mathrm{~g} / \mathrm{ha}$. Benih yang ditabur di persemaian menghasilkan bibit berumur 1.5 bulan dan siap untuk pindah tanam. Tanaman terung merupakan tanaman semusin yang pemanenannya lebih dari satu kali dan biasanya dibongkar apabila panenan terakhir sudah tidak memadai lagi. Sehingga rotasi produksi cukup lama menyebabkan benih sisa terancam kedaluwarsa. Benih yang telah lewat kedaluwarsa akan mengalami deteriorasi dimana viabilitas benih telah mengalami penurunan terlebih jika penanganan dan penyimpanan kurang baik. Deteriorasi merupakan satu proses yang dialami oleh setiap benih setelah benih mencapai masak fisiologis dan akan berlangsung selama benih tersebut mengalami proses pengolahan, pengemasan, penyimpanan dan juga transportasi. Menurut Copeland dan McDonald (2001) gejala deteriorasi benih merupakan proses yang sangat kompleks. Gejala tersebut dapat disebabkan oleh perubahan morfologis, kebocoran membran sel selama proses imbibisi, serta berkurangnya aktivitas enzim dan proses respirasi. Menanam benih yang telah mengalami deteriorasi beresiko menurunkan hasil komoditas serta pendapatan petani.

Benih yang telah mengalami deteriorasi dapat ditingkatkan viabilitasnya melalui perlakuan invigorasi. Invigorasi merupakan suatu perlakuan yang diberikan terhadap benih sebelum penanaman dengan tujuan memperbaiki perkecambahan dan pertumbuhan kecambah. Invigorasi yang digunakan dalam penelitian ini yaitu teknik osmoconditioning. Osmoconditioning adalah perlakuan hidrasi benih terkontrol dengan larutan berpotensial osmotik rendah, sedangkan potensial matriks dapat diabaikan selama periode tertentu dengan tertundanya perkecambahan (Ilyas, 2012). Beberapa jenis osmotik yang dapat digunakan sebagai larutan osmoconditioning antara lain PEG dan KNO3.

Poli Etilen Glikol (PEG) adalah salah satu senyawa yang sering digunakan dalam osmoconditioning. PEG memiliki ukuran molekul besar sehingga imbibisi pada larutan ini berlangsung perlahan ke dalam benih dan durasi penyerapan air diperpanjang sehingga menyebabkan terjadinya penguatan (perbaikan) permiabilitas membran plasma dan memperkecil kehilangan elektrolit sel (Ruliyansyah, 2011). Khan et al. (2017) melaporkan bahwa perlakuan PEG selama 24 jam menunjukkan perkecambahan tertinggi, meningkatkan panjang kecambah, panjang akar, dan bobot kering lebih baik dibandingkan dengan kontrol. Pemberian PEG konsentrasi $3 \%$ selama 2 jam dilaporkan dapat meningkatkan daya berkecambah dan keserempakan tumbuh benih Hibiscus cannabinus L. masing-masing 32,67\% dan 39,53\% (Susanti, 2014). Perlakuan osmoconditioning selama 12 jam pada benih kedelai hitam secara efektif menghasilkan nilai keserempakan tumbuh, panjang hipokotil, daya berkecambah, kecepatan tumbuh dan bobot kering kecambah normal yang paling tinggi (Yuanasari et al., 2015). Potassium nitrat 
$\left(\mathrm{KNO}_{3}\right)$ merupakan larutan yang direkomendasikan oleh ISTA sebagai perangsang perkecambahan dan pematah dormansi (Copeland dan McDonald, 2001). Hasil penelitian Lara et al. (2014) pada benih tomat menunjukkan bahwa perlakuan priming dengan KNO3 meningkatkan germination time (t) dan germination rate (v) lebih baik dbandingkan kontrol. Mazidah dan Ardhiyah (2019) menunjukkan bahwa pemberian $\mathrm{KNO}_{3} 1 \%$ selama 4 jam pada benih kedelai edamame meningkatkan viabilitas lebih baik dibandingkan kontrol. Osmoconditioning juga dapat menambahkan zat pengatur tumbuh. Ekstrak bawang merah mengandung auksin yang berperan mengatur pembesaran dan pemanjangan sel (Dule dan Murdaningsih, 2017) serta dapat meningkatkan viabilitas benih. Konsentrasi ekstrak bawang merah terbaik terdapat pada konsentrasi ekstrak bawang merah 25\% dalam meningkatkan viabilitas benih tomat kadaluarsa (Lubis et al. 2018). Percobaan ini bertujuan untuk melihat pengaruh beberapa teknik osmoconditioning terhadap mutu fisiologis benih terung yang telah melewati masa kadaluarsa.

\section{METODE PENELITIAN}

Penelitian dilaksanakan pada bulan Mei sampai dengan Juli 2020 di Kecamatan Bambanglipuro, Kabupaten Bantul, Daerah Istimewa Yogyakarta. Benih yang digunakan adalah benih terung ungu yang diproduksi oleh UPTD - BPPTPH, Dinas Pertanian Provinsi D.I. Yogyakarta dengan masa kadaluarsa 26 Juli 2017.

Penelitian ini terdiri dari 9 perlakuan yaitu : kontrol, air hangat, ekstrak bawang merah, Poli Etilen Glikol (PEG) 1\%, PEG 3\%, PEG 5\%, KNO3 2 gr/L, KNO3 4 gr/L, dan KNO3 6 gr/L. Masingmasing perlakuan terdiri dari 25 butir benih dan diulang 3 kali. Perlakuan Perendaman dengan Air Hangat : Benih terung kadaluarsa direndam dengan air hangat $\left(36^{\circ} \mathrm{C}\right)$ selama 24 jam sebelum uji mutu fisiologis (Refina, 2018). Perlakuan Osmoconditioning dengan Ekstrak Bawang Merah : Umbi bawang merah dikupas dan dibersihkan dari kulitnya kemudian dihaluskan dengan juicer dan disaring. Larutan hasil saringan dijadikan sebagai larutan stok dengan konsentrasi 100\%. Untuk membuat larutan dengan konsentrasi 25\% dilakukan dengan mengencerkan larutan stok sebanyak $25 \mathrm{ml}$ ditambah $75 \mathrm{ml}$ aquades. Benih terung kadaluarsa direndam dalam larutan ekstrak bawang merah selama 24 jam (Lubis et al., 2018). Perlakuan Osmoconditioning dengan Poli Etilen Glikol (PEG) : benih terung kadaluarsa direndam selama 2 jam dalam larutan PEG 6000 dengan konsentrasi 1\%, 3\%, dan 5\% (Dahrul, 2019) mengikuti rumus :

$$
\mathrm{V} 1 . \mathrm{M} 1=\mathrm{V} 2 . \mathrm{M} 2
$$

Perlakuan Osmoconditioning dengan $\mathrm{KNO}_{3}$ : benih terong kadaluarsa direndam larutan $\mathrm{KNO}_{3} 100 \mathrm{ml}$ dengan konsentrasi larutan 2 gr/L, 4 gr/L, dan 6 gr/L selama 24 jam. (Kuspriyanto, 2016). Pengujian dan Pengamatan Mutu Fisiologis Benih Terung : Pengujian daya berkecambah menurut ISTA (2018), pengujian daya kecambah benih terung kadaluarsa dilakukan pada substrat kertas stensil yaitu metode UDK (uji di atas kertas). Variabel pengamatan meliputi, Persentase Daya Berkecambah (DB), Potensi Tumbuh Maksimum (PTM), Indeks Vigor (IV), Bobot Kering Kecambah Normal (BKKN), Tinggi Kecambah, dan Panjang Akar. Data dianalisis menggunakan sidik ragam untuk mengetahui pengaruh perlakuan. Apabila analisis ragam menunjukkan keragaman nyata dilanjutkan dengan Duncan's Multiple Range Test (DMRT) taraf 5\%. 


\section{HASIL DAN PEMBAHASAN}

\section{Viabilitas Potensial Benih}

Viabilitas potensial diartikan sebagai kemampuan benih untuk tumbuh, berkecambah, dan berproduksi normal pada lingkungan tumbuh optimum. Menurut Sadjad et al. (1999) Daya Berkecambah (DB) dan Potensi Tumbuh Maksimum (PTM) merupakan tolok ukur viabilitas potensial. Pada penelitian ini, rentang waktu batas masa kadaluarsa benih yang tertera di kemasan yaitu 26 Juli 2017 hingga waktu pelaksanaan penelitian tepatnya tanggal awal pengujian viabilitas benih yaitu 11 Mei 2020 berkisar kurang lebih 2 tahun 10 bulan. Pada Tabel 1, dapat dilihat bahwa dalam rentang waktu lewat batas kadaluarsa tersebut, benih terung kadaluarsa mengalami kehilangan viabilitas potensial dari tolok ukur DB sebesar 65\%. Daya berkecambah yang tertera di label kemasan benih adalah $85 \%$ sebagai hasil pengujian laboratorium syarat lulus sertifikasi dan pelabelan sedangkan hasil pengujian daya berkecambah kontrol pada penelitian ini mencapai $20 \%$. Benih terung secara signifikan telah mengalami deteriorasi (kemunduran mutu benih) di penyimpanan. Kemunduran benih merupakan suatu proses yang dialami oleh benih setelah benih mencapai masak fisiologis dan akan berlangsung selama benih mengalami proses pengolahan, pengemasan, penyimpanan dan juga transportasi. Menurut Justice dan Bass (2002), selama penyimpanan benih proses fisiologis tetap berlangsung sehingga harus di usahakan agar proses ini berjalan seminimal mungkin. Ketahanan benih untuk disimpan beragam tergantung pada jenis dan cara penyimpanannya (Sutopo 2002). Menurut Schmidt (2000) benih ortodoks tahan terhadap pengeringan dan suhu penyimpanan rendah yaitu $0-5{ }^{\circ} \mathrm{C}$ dengan kadar air $5-7 \%$. Benih yang telah kadaluarsa memiliki daya berkecambah yang rendah karena habisnya cadangan makanan di dalam benih disebabkan respirasi tetap berjalan, sehingga energi untuk perkecambahan berkurang.

Kemunduran benih yang bersifat ireversibel dan tak dapat dihindari, laju deteriorasi yang cepat dapat dikendalikan dengan pemanenan yang tepat, pengeringan dan teknik penyimpanan yang tepat.Ada beberapa faktor yang diketahui mempengaruhi laju kemunduran benih selama penyimpanan. Faktor suhu tinggi dan kelembaban selama penyimpanan meningkatkan laju kerusakan benih (McDonald, 1999; Pukacka et al., 2009) dan penurunan salah satu dari faktor-faktor ini secara signifikan meningkatkan vigor dan viabilitas selama penyimpanan benih (Castellió, Matiacevich, Buera, dan Maldonado, 2010).

Tabel 1. Pengaruh Perlakuan Osmoconditioning terhadap Viabilitas Potensial Benih Terung Kadaluarsa

\begin{tabular}{ccc}
\hline Perlakuan & Daya Berkecambah (\%) & Potensi Tumbuh Maksimum (\%) \\
\hline Kontrol & $20.00 \mathrm{abc}$ & 37.33 \\
AH & $16.00 \mathrm{c}$ & 40.00 \\
BW & $16.00 \mathrm{c}$ & 40.00 \\
KNO3 2 g/L & $26.67 \mathrm{abc}$ & 38.67 \\
KNO3 4 g/L & $30.67 \mathrm{a}$ & 36.00 \\
KNO3 6 g/L & $28.00 \mathrm{ab}$ & 38.67 \\
PEG 1\% & $21.33 \mathrm{abc}$ & 40.00 \\
PEG 3\% & $20.00 \mathrm{abc}$ & 38.67 \\
PEG 5\% & $16.89 \mathrm{bc}$ & 40.00 \\
\hline
\end{tabular}

Keterangan : Perlakuan AH (Air Hangat), BW (Bawang Merah). Angka-angka pada kolom yang sama diikuti huruf yang sama menunjukkan hasil yang tidak berbeda nyata pada uji Duncan. 
Tabel 1 menunjukkan bahwa perlakuan osmoconditioning $\mathrm{KNO}_{3} 4 \mathrm{~g} / \mathrm{L}$ dengan $\mathrm{DB}$ 30.67\% mampu meningkatkan daya berkecambah benih terung kadaluarsa berbeda nyata lebih baik dari kontrol dengan DB 20\%. Potassium Nitrat $\left(\mathrm{KNO}_{3}\right)$ telah direkomendasikan oleh International Seed Testing Assosiation (ISTA) sebagai bahan kimia yang digunakan dalam promotor perkecambahan dengan konsentrasi 0.1-0.2\% atau maksimal 2\% (Copeland dan McDonald, 2001). Mekanisme kerja $\mathrm{KNO}_{3}$ terkait dengan aktifitas lintasan pentosa fosfat saat respirasi yang diaktifkan oleh akseptor hidrogen seperti nitrat, nitrit, dan methylene blue, sehingga suplai oksigen cukup bagi perkecambahan (Bewley dan Black, 1943).

Hasil sidik ragam menunjukkan bahwa perlakuan osmoconditioning berpengaruh tidak nyata terhadap Potensi Tumbuh Maksimum (PTM) benih terung kadaluarsa (Tabel 1). Perbedaan penghitungan PTM dan DB adalah DB hanya menghitung kecambah normal dari lot benih yang diamati sedangkan PTM selain menghitung kecambah normal juga mempertimbangkan pertumbuhan kecambah abnormal. Kecambah normal diartikan sebagai kecambah yang menunjukkan potensi untuk berkembang menjadi tanaman yang sempurna ketika ditumbuhkan pada kondisi yang optimum sedangkan kecambah abnormal adalah kecambah yang tidak menunjukkan potensi untuk berkembang menjadi tanaman normal pada kondisi yang optimum dengan mempertimbangkan struktur penting kecambah yaitu sistem perakaran, shoot axis (hipokotil, epikotil, mesokotil, dan terminal bud), kotiledon serta koleoptil (ISTA, 2018). Benih terung yang telah mengalami deteriorasi banyak menghasilkan kecambah abnormal disebabkan karena faktor lama penyimpanan yang menyebabkan perubahan cadangan makanan, kerusakan organ penting dari embrio, kebocoran membran sel, serta kehilangan energi untuk perkecambahan. Kebocoran ini menyebabkan benih menjadi kekurangan bahan yang dapat dirombak untuk menghasilkan energi, yang dibutuhkan untuk proses perkecambahan, akibatnya akan banyak ditemukan kecambah abnormal atau bahkan benih yang tidak mampu berkecambah sama sekali (Ruliyansyah, 2011). Tolok ukur PTM yang tidak nyata mengindikasikan benih terung kadaluarsa masih memiliki potensi tumbuh membentuk kecambah abnormal namun perlakuan osmoconditioning tidak memiliki pengaruh berbeda terhadap pembentukan kecambah abnormal pada masing-masing perlakuan.

\section{Vigor Benih}

Vigor merupakan indikator yang dapat menunjukkan bagaimana benih tumbuh pada kondisi lapang kurang optimum. Tolok ukur ini digunakan untuk melihat kekuatan tumbuh benih saat ditanam pada kondisi lapang yang bervariasi. Benih yang memiliki vigor kekuatan tumbuh tinggi saat diuji di laboratorium dapat tumbuh normal, serempak, serta berproduksi tinggi dengan kualitas baik saat ditanam di lapang (Aruan et al., 2018).

Perlakuan KNO3 2 g/L mampu meningkatkan Indeks Vigor (IV) dengan nilai 6.67\% lebih baik namun tidak berbeda nyata dari kontrol dengan IV 4\%. Rendahnya nilai indeks vigor akibat deteriorasi benih disebabkan masih berjalannya aktivitas metabolisme benih seperti respirasi dan oksidasi lemak selama penyimpanan. Aktivitas fisiologi tersebut menggunakan cadangan makanan di dalam benih sehingga energi berkurang saat perkecambahan yang dapat menyebabkan presentase vigor benih menurun (Puspitaningtyas et al., 2018). Rendahnya indeks vigor benih terung kadaluarsa menggambarkan bahwa perlakuan invigorasi belum dapat meningkatkan vigor kekuatan tumbuh benih terung. 
Agritrop, Vol. 18 (2): 162 - 170

Tabel 2. Pengaruh Perlakuan Osmoconditioning terhadap Vigor Benih Terung Kadaluarsa

\begin{tabular}{cll}
\hline Perlakuan & IV $(\%)$ & BKKN \\
\hline Kontrol & $4.00 \mathrm{ab}$ & $0.00600 \mathrm{c}$ \\
AH & $1.33 \mathrm{bc}$ & $0.00500 \mathrm{c}$ \\
BW & $1.33 \mathrm{bc}$ & $0.00567 \mathrm{c}$ \\
KNO3 $2 \mathrm{~g} / \mathrm{L}$ & $6.67 \mathrm{a}$ & $0.01033 \mathrm{ab}$ \\
KNO3 $4 \mathrm{~g} / \mathrm{L}$ & $4.00 \mathrm{ab}$ & $0.01100 \mathrm{a}$ \\
KNO3 6 g/L & $1.33 \mathrm{bc}$ & $0.01100 \mathrm{a}$ \\
PEG 1\% & $1.33 \mathrm{bc}$ & $0.00733 \mathrm{abc}$ \\
PEG 3\% & $0.00 \mathrm{c}$ & $0.00667 \mathrm{bc}$ \\
PEG 5\% & $0.00 \mathrm{c}$ & $0.00667 \mathrm{bc}$ \\
\hline
\end{tabular}

Keterangan : Perlakuan AH (Air Hangat), BW (Bawang Merah). Angka-angka pada kolom yang sama diikuti huruf yang sama menunjukkan hasil yang tidak berbeda nyata pada uji Duncan

Perlakuan osmoconditioning menggunakan $\mathrm{KNO}_{3} 4 \mathrm{~g} / \mathrm{L}$ dan $\mathrm{KNO} 36 \mathrm{~g} / \mathrm{L}$ mampu meningkatkan Bobot Kering Kecambah Normal (BKKN) benih terung kadaluarsa dengan nilai sama antar kedua perlakuan yaitu $0.011 \mathrm{~g}$ dan nyata lebih baik dibandingkan dibandingkan kontrol dengan nilai BKKN 0.006 g. Tolok ukur BKKN menunjukkan kemampuan benih memanfaatkan cadangan makanan di dalama benih untuk membentuk biomassa kecambah normal. Nilai BKKN berhubungan dengan vigor benih dimana benih yang memiliki vigor tinggi mampu menghasilkan berat kering kecambah normal yang tinggi pada kondisi optimum dan sub optimum.

\section{Kemampuan Pemanfaatan Cadangan Makanan dalam Pembentukan Organ Perkecambahan Benih Terung Kadaluarsa}

Perlakuan osmoconditioning yang diberikan memberikan pengaruh nyata terhadap tolok ukur tinggi kecambah. Pada Gambar 1, dapat dilihat bahwa perlakuan $\mathrm{KNO}_{3} 2 \mathrm{~g} / \mathrm{L}$ memiliki tinggi kecambah paling tinggi sebesar $4.5 \mathrm{~cm}$ yang nyata lebih baik dibandingkan kontrol yaitu sebesar $2.74 \mathrm{~cm}$. Hal ini diduga karena benih yang mendapat perlakuan osmoconditioning dapat melakukan imbibisi lebih cepat dan berdampak pada aktivitas hormon dan enzim perkecambahan aktif lebih awal. Osmoconditioning merupakan teknologi seed enhancement yang mampu meningkatkan kecepatan serta keseragaman pertumbuhan benih sehingga perkecambahan berlangsung lebih singkat (Sudrajat, 2018). Tinggi perlakuan KNO3 2\% yang berbeda nyata lebih baik dari kontrol mengindikasikan perkecambahan terjadi lebih awal dibandingkan kontrol. Hal ini memberi keuntungan saat benih ditanam dilapang yaitu kecambah akan mampu bersaing dengan gulma dalam pemanfaatan cahaya matahari untuk fotosintesis maupun faktor pertumbuhan lainnya.

Pengamatan pada tolok ukur panjang akar (Gambar 2) menunjukkan bahwa perlakuan PEG 5\% memiliki panjang akar yang dengan nilai paling tinggi yaitu $4.41 \mathrm{~cm}$ tidak berbeda nyata dengan kontrol dengan panjang akar $4.08 \mathrm{~cm}$. Sedangkan, panjang akar terpendek secara umum dihasilkan oleh perlakuan KNO3 dengan nilai panjang akar terpendek pada konsentrasi $6 \mathrm{~g} / \mathrm{L}$ yaitu $2.62 \mathrm{~cm}$. Panjang akar berkaitan dengan adaptasi morfologi dan fisiologi kecambah dalam memenuhi kebutuhan air agar proses metabolisme berlangsung normal. Di awal pertumbuhan, benih belum berfotosintesis dan bermetabolisme dari energi yang diperoleh dari cadangan makanan (endospema) yang akan aktif bila imbibisi berlangsung optimal. Tingginya nilai panjang akar akibat pengaruh PEG 5\% diduga karena semakin tinggi konsentrasi PEG menyebabkan imbibisi berlangsung semakin lambat. Larutan yang mengandung PEG dengan molekul yang besar menyebabkan proses masuknya air ke dalam benih berlangsung lambat. Rahmah et al. 2020. Dalam beberapa penelitian, PEG biasa dipergunakan untuk simulasi lingkungan 
cekaman kekeringan karena dapat menurunkan potensial air media (Rahmah et al., 2020; Rao \& Jabben 2013) serta digunakan untuk screening genotipe yang toleran kekeringan (Verslues et al., 2006).

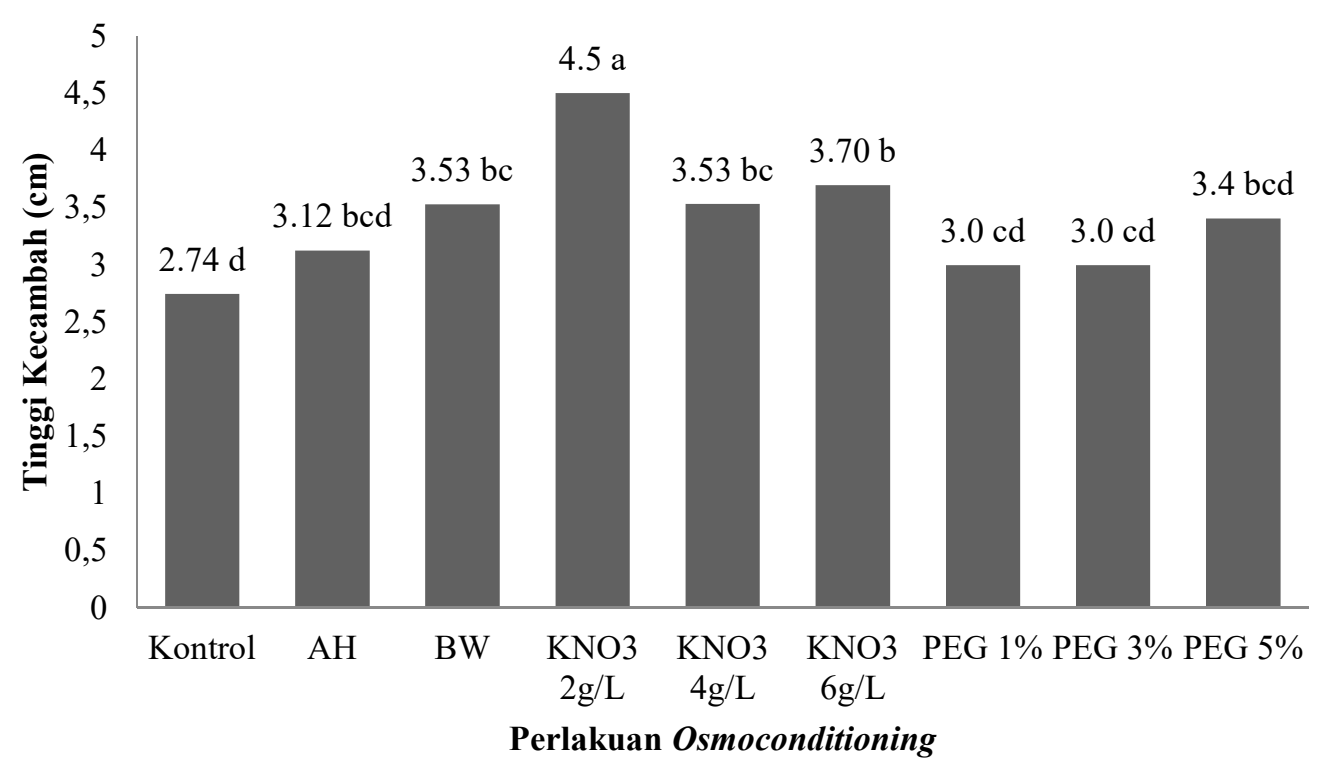

Gambar 1 Pengaruh perlakuan osmoconditioning terhadap tinggi kecambah benih terung kadaluarsa. Keterangan : Perlakuan AH (Air Hangat), BW (Bawang Merah). Angka-angka pada kolom yang sama diikuti huruf yang sama menunjukkan hasil yang tidak berbeda nyata pada uji Duncan

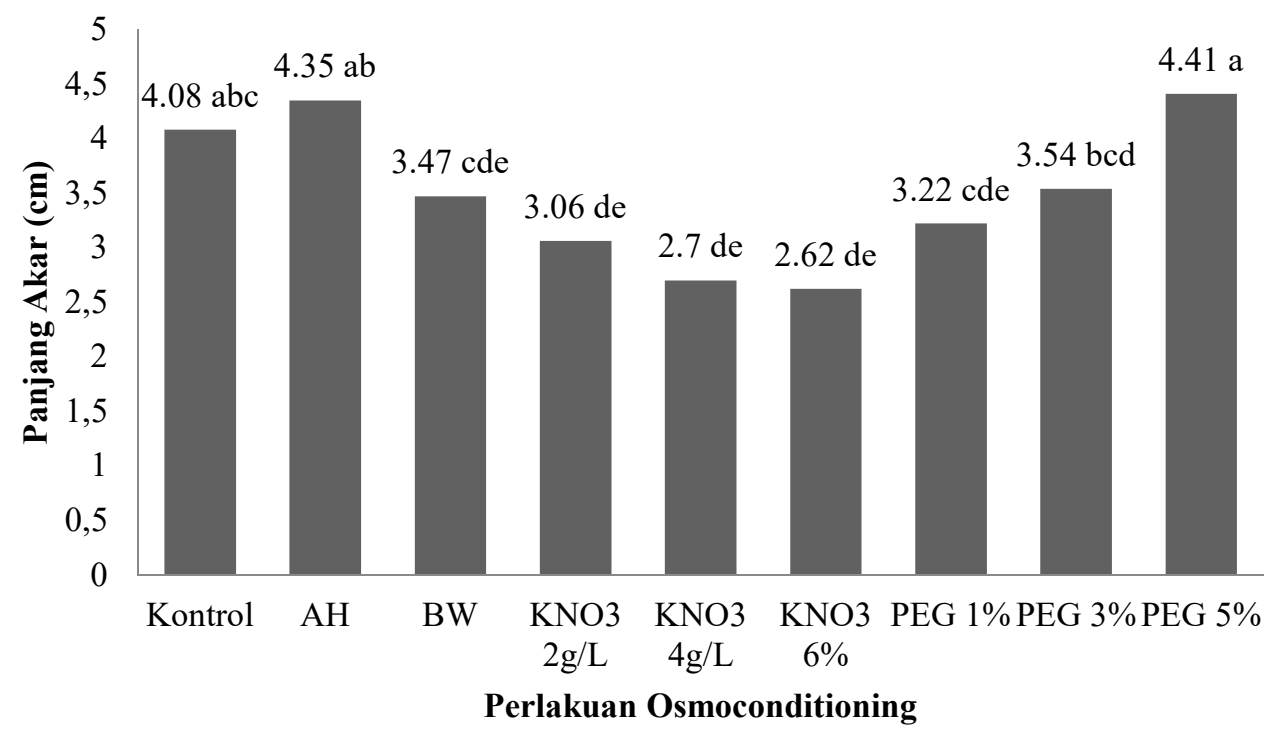

Gambar 2 Pengaruh perlakuan osmoconditioning terhadap panjang akar benih terung kadaluarsa. Keterangan : Perlakuan AH (Air Hangat), BW (Bawang Merah). Angka-angka pada kolom yang sama diikuti huruf yang sama menunjukkan hasil yang tidak berbeda nyata pada uji Duncan. 


\section{KESIMPULAN}

Dari penelitian dan pembahasan, maka diperoleh kesimpulan sebagai berikut : (1) Benih terung kadaluarsa 2 tahun 10 bulan tekah mengalami deteriorasi dengan viabilitas $<80 \%$, (2) Invigorasi benih terung kadaluarsa melalui perlakuan invigorasi pada benih yang viabilitasnya rendah $(<72 \%)$, organelprganel sel pada benih sudah terlalu rusak sehingga sulit untuk dipulihkan kembali, (3) Osmoconditioning menggunakan $\mathrm{KNO}_{3}$ mampu meningkatkan viabilitas maupun vigor benih terung kadaluarsa nyata lebih baik dibandingkan kontrol dari pengamatan daya berkecambah, indeks vigor, bobot kering kecambah normal, serta tinggi kecambah, (4) Perlekuan osmoconditioning dengan PEG menghasilkan panjang akar paling besar sebagai respon dari benih terhadap lambatnya imbibisi yang cenderung mengarah ke kondisi kekeringan.

\section{DAFTAR PUSTAKA}

Annisa, D., 2019, Invigorasi Benih Sejati Bawang Merah (Allium ascalonicum L.) dengan Metode Osmoconditioning pada Berbagai Konsentrasi PEG - 6000, Tesis, Universitas Andalas, Padang.

Aruan. R.B., Nyana I.D.N., Siadi I.K., Raka I.G.N., 2018, Toleransi Penundaan Prosesing terhadap Mutu Fisik dan Mutu Fisiologis Benih Kedelai (Glycine max L. Merril). E-Jurnal Agroekoteknologi Tropika. Vol. 7(2).

BPS. 2019. Statistik Tanaman Sayuran dan Buah-Buahan Semusim Indonesia 2018. BPS.RI. Jakarta, 101 hal.

Copeland, L.O. McDonald. M.B., 2001, Principles of Seed Science and Technology, Kluwer Academic Publisher, New York.

Dule, B.R., Murdaningsih, 2019, Penggunaan Auksin Alami sebagai Zat Pengatur Tumbuh (ZPT) terhadap Pertumbuhan Stek Bibit Jambu Air (Syszygium samarangense). AGRICA, Vol.10(2):52 -61.

Ilyas S. 2012. Ilmu dan Teknologi Benih. Bogor (ID): IPB Pr.

ISTA, 2018, International Rules for Seed Testing, The International Seed Testing Association.Basserdorf, CH, Switzerland.

Khan, AZ., Shah, T., Khan, S., Reilman, A., Akbar, H., Muhammad, A., Khalil, S.K. 2017. Influence of Seed Invigoration Techniques on Germination and Seedling Vigor of Maize (Zea mays L.) Certerari Agronomice in Moldova. Vol. L. No. 3 (171)/2017 : $61-70$.

Kuspriyanto, D., 2016, Respon Daya Berkecambah dan Vigor Benih Terong (Solanum melongena) terhadap Berbagai Metode Pematahan Dormansi pada Media Pasir, Skripsi, Universitas Muhammadiyah Jember, Jember.

Lara T.S., Lira, J.M., Rodrigues, A.C., Rakocevic M., Alvarenga A.A., 2014, Potassium Nitrate Priming Affects the Activity of Nitrate Reductase and Antioxidant Enzymes in Tomato Germination, Journal of Agricultural Science, Vol. 6 (2).

Lubis, R.R., Kurniawan, T., Zuyasna. 2018. Invigorasi Benih Tomat Kadaluarsa dengan Ekstrak Bawang Merah pada Berbagai Konsentrasi dan Lama Perendaman, Jurnal Ilmiah Mahasiswa Pertanian, Vol.3(4).

Mazidah, N., Ardhiyah, N., 2019, Uji Invigorasi Benih Menggunakan Osmoconditioning terhadap Viabilitas, Vigor dan Hasil pada Benih Edamame (Glycine Max (L) Merril), Skripsi, Universitas Muhammadiyah Malang.

Muldiana, S, Rosdiana, 2017, Respon Tanaman Terung (Solanum malongena L.) terhadap Interval Pemberian Pupuk Organik Cair Dengan Interval Waktu yang Berbeda, Prosiding Seminar Nasional 2017 Fak. Pertanian UMJ, 8 November 2017. Hal : 155 - 162.

Pusat Data dan Sistem Informasi Pertanian. 2018. Statistik Konsumsi Pangan 2018. Sekjen Kementerian Pertanian.http://epublikasi.setjen.pertanian.go.id/epublikasi/StatistikPertanian/2018/Konsumsi/Statistik_Konsum si_Pangan_Tahun_2018/files/assets/basic-html/page64.html. diakses tgl 8 November 2020. 
Rahmah, N.I., Ilyas, S., Setiawan, A., 2020. Evaluation of Bambara Groundnut (Vigna subterranea L. Verdc.) Genotypes for Drought Tolerance at Germination Stage, SABRAO Journal of Breeding and Genetics. Vol. 52 (1) 45-63.

Rao, S,, Jabben, F., 2013, In Vitro Selection and Characterization of Polyethylene Glycol (PEG) Tolerant Callus Lines and Regeneration of Plantlets from The Selected Callus Lines in Sugarcane (Saccharum officinarum L.). Physiology Moleculer Biology Plants. Vol. 19: 261-268.

Refina, S., 2018, Pertumbuhan Bibit Terung Putih (Solanum melongena L.) pada Volume Media Semai, Skripsi, Institut Pertanian Bogor, Bogor.

Ruliyansyah, A. 2011. Peningkatan Performansi Benih Kacangan dengan Perlakuan Invigorasi. Jurnal Perkebunan dan Lahan Tropika. 1(1):13-18.

Sadjad, S., Murniati, E., Ilyas, S., 1999, Parameter Pengujian Vigor Benih dari Komparatif ke Simulatif, Grasindo, Jakarta.

Sudrajat L.H., 2018, Pengaruh Osmoconditioning Menggunakan PEG 6000 terhadap Viabilitas Benih Pepaya Gunung, Skripsi, Jurusan Biologi, Fakultas Sains dan Teknologi, Universitas Maulana Malik Ibrahim, Malang.

Susanti, E., 2014, Pengaruh Osmoconditioning dengan PEG (Polyethylene Glycol) 6000 terhadap Viabilitas Benih Kenaf (Hibiscus cannabinus L.), Skripsi, Jurusan Biologi, Fakultas Sains dan Teknologi, Universitas Islam Negeri Maulana Malik Ibrahim, Malang.

Verslues, P.E, Agarwal, M., Agarwal, K.S., Zhu, J., 2006, Methods and Concepts in Quantifying Resistance to Drought, Salt, and Freezing, Abiotic Stresses that Affect Plant Water Status. Plant J. Vol. 45: 523-539

Yuanasari, B.S., Kendarini, N., dan Saptadi, D., 2015, Peningkatan Viabilitas Benih Kedelai Hitam (Glycine Max L. Merr) melalui Invigorasi, Jurnal Produksi Tanaman, Volume 3 (6) : 518 - 527. 